\title{
Stockpiled Forage Kochia to Maintain Beef Cows During Winter
}

\author{
Blair L. Waldron, ${ }^{1}$ Dale R. ZoBell, ${ }^{2}$ Kenneth C. Olson, ${ }^{2}$ \\ Kevin B. Jensen, ${ }^{1}$ and Donald L. Snyder ${ }^{3}$ \\ Authors are ${ }^{1}$ Research Geneticists, USDA-ARS Forage and Range Research Lab, Logan, UT 84322-6300; \\ ${ }^{2}$ Professors, Animal Science Department, Utah State University, Logan, UT 84322-4815; and \\ ${ }^{3}$ Professor, Economics Department, Utah State University, Logan, UT 84322-4800.
}

\begin{abstract}
Extending grazing into the winter, as opposed to feeding of harvested forages, can increase the sustainability of ranching in the western US. This study was conducted to determine the economic value of grazing stockpiled forage kochia (Kochia prostrata [L.] Scrad.) and crested wheatgrass (Agropyron desertorum [Fisch. Ex Link] Schultes) during the fall and winter. Changes in cow body weight, body condition score, and ultrasound backfat were compared for late-gestation cows grazing forage kochiacrested wheatgrass pastures vs. those fed alfalfa (Medicago sativa L.) hay in drylot. The study was conducted from early November to late January for 2 consecutive years near Promontory, Utah. Forage availability and nutritional quality were monitored throughout the experiment. Cows grazing stockpiled forages did not receive any protein or energy supplements. Forage kochia comprised approximately $70 \%$ of available forage, with November crude protein content of 116 and $76 \mathrm{~g} \cdot \mathrm{kg}^{-1}$ in years 1 and 2, respectively. Nutritional quality declined throughout the season, presumably mostly because of removal of higher-quality forage by preferential grazing as opposed to weathering. Averaged over years, cows grazing forage kochia-grass gained body weight $(19 \mathrm{~kg})$, increased in body condition ( 0.3 points), and maintained backfat thickness, finishing well within the range considered optimum for onset of calving and return to estrus. Pasture- vs. drylot-fed cows did not differ with regard to changes in body weight or body condition score. Both treatments increased backfat in year 1, when initial backfat was less than $0.5 \mathrm{~cm}$, but both treatments resulted in loss of backfat in year 2, when initial backfat was greater than $1.0 \mathrm{~cm}$. Grazing was more economical, costing $\$ 0.24 \cdot \mathrm{cow}^{-1} \cdot \mathrm{d}^{-1}$ less than feeding alfalfa hay in drylot. Forage kochia can be used on western rangelands to extend grazing into the fall and winter, thereby improving the profitability of beef production.
\end{abstract}

\section{Resumen}

Extender el apacentamiento hasta el invierno, como estrategia opuesta a la alimentación con forrajes cultivados, puede incrementar la sostenibilidad de las operaciones ganaderas del oeste de Estados Unidos. Este estudio se condujo para determinar el valor económico de apacentar forraje acumulado en pie de "Kochia" (Kochia prostrata [L.] Scrad.) y "crested wheatgrass" (Agropyron desertorum [Fisch. Ex Link] Schultes) durante el otoño e invierno. Cambios en el peso corporal, la condición corporal y grasa del lomo medida con ultrasonido fueron comparados entre vacas en estado final de gestación apacentando praderas de "Kochia"-"Crested wheatgrass" versus vacas alimentadas en corral con heno de "Alfalfa" (Medicago sativa L.). El estudio se llevo a cabo cerca de Promontory, Utah de inicios de Noviembre a fines de Enero durante dos años consecutivos. La disponibilidad de forraje y la calidad nutricional fueron monitoreadas a lo largo del experimento. Las vacas apacentando los forrajes acumulados en pie no recibieron ningún suplemento ni proteico ni energético. El forraje de "Kochia" aportó aproximadamente el $70 \%$ del forraje disponible, con un contenido de proteína cruda en Noviembre de $116 \mathrm{y} 76 \mathrm{~g} \cdot \mathrm{kg}^{-1}$ en el año 1 y 2, respectivamente. La calidad nutricional disminuyó a través de la estación de apacentamiento, presumiblemente debido en gran parte a la remoción de forraje de alta calidad por el apacentamiento preferencial como opuesto al intemperismo. Promediado a través de los años, las vacas apacentando "Kochia-zacate" ganaron peso corporal $(19 \mathrm{~kg})$, incrementaron su condición corporal (0.3 puntos) y mantuvieron el espesor de la grasa del lomo, terminando bien dentro del rango considerado como optimo para el inicio de la época de pariciones y regresar al estro. Las vacas apacentando las praderas versus las alimentadas en estabulación no difirieron en los cambios de peso o condición corporal. Ambos tratamientos incrementaron la grasa del lomo en el primer año, cuando la grasa inicial fue menos de $0.5 \mathrm{~cm}$, pero en el segundo año, ambos tratamientos resultaron en perdida de grasa del lomo cuando la grasa inicial del lomo fue mayor a $1 \mathrm{~cm}$. El apacentamiento fue más económico, costando $\$ 0.24 \cdot \mathrm{vaca}^{-1} \cdot \mathrm{día}^{-1}$ menos que la alimentación con alfalfa en corral. El forraje de "Kochia" puede ser utilizado en los pastizales del oeste para extender el apacentamiento hasta otoño e invierno, por lo tanto mejorando la rentabilidad de la producción de carne.

Key Words: backfat, body condition, economics, fall grazing, forage quality, crested wheatgrass

Joint contribution of the USDA-ARS and the Utah Agricultural Experiment Station. Utah Agricultural Experiment Station Journal Paper No. 7725.

Mention of a trademark, proprietary product, or vendor does not constitute a guarantee or warranty of the product by the USDA or Utah State University. Correspondence: Dr Blair L. Waldron, USDA-ARS Forage and Range Research Lab, 696 N. 1100 E., Logan, UT 84322-6300. Email: blair.waldron@usu.edu 


\section{INTRODUCTION}

Winter feeding costs limit economic sustainability of livestock production in the Intermountain West, where they often account for $50 \%$ to $70 \%$ of input costs per cow per year (Majerus 1992; Hathaway 2003; McCartney et al. 2004). Willms et al. (1993) reported that extending the grazing season into the fall and winter could increase economic returns between $\$ 47$ and $\$ 90$ per cow, and McCartney et al. (2004) suggested that extending the grazing season has the potential savings of $\$ 0.25 \cdot \mathrm{cow}^{-1} \cdot \mathrm{d}^{-1}$, not including cost of winter facilities, harvesting and feeding hay, or manure removal.

The nutritional quality and potential role of stockpiled drought-tolerant grasses to extend the grazing season on western ranges has been evaluated (Majerus 1992; Willms et al. 1993; Houseal and Olson 1996; Jensen et al. 2002; Jefferson et al. 2004). However, without exception, these studies showed that stockpiled range grasses do not meet the NRC (1996) minimum protein level recommendations for ruminant livestock. Abundant studies have shown that livestock lose body weight, body condition, and backfat and are not in optimum condition for parturition when wintered on stockpiled grass without supplementation (Knipfel 1977; Cochran et al. 1986; Willms et al. 1993; Adams et al. 1994; Villalobos et al. 1997; Freeze et al. 1999). Supplementation with high-protein sources has improved animal performance when grazing dormant stockpiled grasses; however, this can be costly and require additional labor (Cochran et al. 1986; Adams et al. 1994; Villalobos et al. 1997; Hitz and Russell 1998; Freeze et al. 1999; McCartney et al. 2004). Alternatively, some rangeland shrubs have been shown to meet ruminant protein requirements during the fall and winter and may act synergistically in mixes with grasses where the grass component overcomes the shrub's lack of digestible energy (Cook 1972; Otsyina et al. 1982; Gade and Provenza 1986).

Forage kochia (Kochia prostrata [L.] Scrad.), sometimes called prostrate kochia, prostrate summer cypress, or Bassia prostrata, is a long-lived, perennial, semievergreen half-shrub well adapted to western US rangelands (Harrison et al. 2000). It is native to the heavily grazed arid and semiarid rangeland regions of Central Eurasia and was first introduced to the US in the early 1960s (Harrison et al. 2000). Forage kochia is different from the weed annual kochia (Kochia scoparia L.), in that forage kochia is a perennial semishrub, will not spread into perennial plant stands, and is not known to contain toxic compounds (Harrison et al. 2000). Many consider forage kochia an important plant because of its potential to restore function and desired use to degraded western rangelands. It has been shown that forage kochia is broadly adapted to semiarid rangelands (McArthur et al. 1974; Blauer et al. 1993; McArthur et al. 1996; Harrison et al. 2000), has high salt and alkali tolerance (Francois 1976; Romo and Haferkamp 1987), is competitive against the annual noxious weeds cheatgrass (Bromus tectorum L.) and halogeton (Halogeton glomeratus [Stephen ex Bieb.] C.A. Mey.) (McArthur et al. 1990; Stevens and McArthur 1990; Clements et al. 1997; Harrison et al. 2000; Monaco et al. 2003), and when planted in greenstrips can be used to stop wildfires in the western US (Harrison et al. 2002). Often, forage kochia is one of few species that can be established on frequently burned, cheatgrass-infested rangelands (Monaco et al. 2003) and may be a useful bridge to reestablishment of native species.

For centuries, forage kochia has been an important fall and winter forage for sheep, cattle, horses, camels, and wildlife in Kazakhstan, Uzbekistan, and surrounding republics (Balyan 1972; Harrison et al. 2000; Waldron et al. 2005). Its nutritive value includes high crude protein during the critical fall/winter grazing period (Davis 1979; Davis and Welch 1985; McKell et al. 1990), low nontoxic levels of oxalates (Davis 1979), and acceptable digestibility and relatively high preference (Nemati 1977; Welch and Davis 1984; Stevens et al. 1985; McKell et al. 1990). Recent evaluation and rancher experience in the western US has suggested that using forage kochia for fall/winter grazing may help reduce winter feeding costs, potentially increasing the sustainability of livestock production in rural areas. The objective of this study was to evaluate forage kochia-grass pastures as a resource to extend cattle grazing into the fall and winter as compared to a traditional harvested hay winter feeding program. Nutritional composition, livestock performance, and economic comparisons were made between the 2 feeding methods. We hypothesized that the forage kochia-grass mixture would provide adequate nutritional quality to maintain beef cows, thus potentially reducing winter feeding costs.

\section{MATERIALS AND METHODS}

A study to compare beef cattle performance when grazing forage kochia-grass pastures vs. feeding harvested alfalfa hay was conducted in Box Elder County, Utah, in cooperation with the USDA Farm Service Agency and the Salt Wells Cattle Company (lat $41^{\circ} 38^{\prime} 119^{\prime \prime} \mathrm{N}$, long $\left.112^{\circ} 27^{\prime} 357^{\prime \prime} \mathrm{W}\right)$. Treatment periods were 05 November 2002 to 28 January 2003 (84 days; year 1) and 05 November 2003 to 22 January 2004 (78 days; year 2).

\section{Cattle Performance Evaluation}

In both years, 42 late-gestation Black Angus beef cattle (average age 7 years) were randomly divided into 6 groups to provide 3 replicate groups of each feed treatment. Control cows were fed free-choice alfalfa hay in drylot pens, and treated cows grazed pastures planted to a mixture of forage kochia and crested wheatgrass. The forage kochia-grass pastures were each 16.2 hectares in size and were created by cross-fencing a field taken out of dryland wheat production in 1996 and planted into the Conservation Reserve Program. Drylot pens were adjacent to the pastures to minimize climate effects. Pastured cows received no protein or energy supplement for the duration of the experiment but had free access to trace-mineralized salt blocks and water, with the water source being the same as for the drylot pens.

In year 1, cattle were evaluated at the initiation of the study and every 28 days for body weight (BW), body condition score (BCS), and backfat thickness (BF). Cows were individually weighed without restriction from feed or water. This was because facilities were inadequate at the research location to hold cattle away from feed and water. To reduce variation in gastrointestinal fill among weigh dates, cattle were always gathered from pastures and pens starting at about 0800 hours 
so that all weights were recorded in midmorning. Body condition score was determined visually by an experienced observer using a range from 1 to 9 , where 1 equaled emaciated and 9 was obese (Wagner et al. 1988). Backfat thickness was measured using a portable ultrasound (Model SSC-210Vet; Aloka, Wallingford, CT). In year 2, BW, BCS, and BF were measured at the initiation and the conclusion of the experiment. A final BCS of 5 to 6 and BF measurements of 0.5 to $0.6 \mathrm{~cm}$ were considered to be optimum for wintering cows, with research showing that this leads to heavier weaned calves and improved pregnancy rates following calving (Perry et al. 1991; Freeze et al. 1999; Olson 2005). Means were reported for initial and final measurements and change over the evaluation period.

\section{Forage Evaluation}

Forage samples were clipped on 04 November 2002, 03 December 2002, 10 January 2003, and 28 January 2003 in year 1 and on 04 November 2003, 05 December 2003, and 09 January 2004 in year 2 in each of the 3 pastures to estimate available forage and quality of that forage. Forage kochia and grass were harvested separately from 30 stratified-random $1-\mathrm{m}^{2}$ plots (10 in each pasture) that were considered representative of the composition of each pasture. In year 2 , snow cover precluded stratified-location sampling during December and January; thus, during this time, samples were taken completely at random locations. Forage samples were clipped to a stubble height of $2.5 \mathrm{~cm}$ for grass and $10 \mathrm{~cm}$ for forage kochia, based upon the assumption that approximately $90 \%$ to $95 \%$ of total forage would be available and could be utilized by cattle. In year 2, snow cover on 05 December and 09 January required manual removal of the snow prior to clipping, resulting in some trampling and other associated losses. These losses were considered to be realistic for losses occurring during grazing.

Forage samples were dried to constant weight at $60^{\circ} \mathrm{C}$, weighed, then double-ground with a Wiley and Cyclone mill to pass through a $1-\mathrm{mm}$ screen, and scanned with a Model 6500 near infrared reflectance spectroscopy instrument (Pacific Sci. Instruments, Silver Spring, MD). NIRSystems software was used to calibrate existing equations so that they were appropriate for the grass or forage kochia. Random samples were selected from each year and harvest and used as a calibration data set for wet laboratory analyses. Validations of the new equations were determined from a different set of samples for crude protein $(\mathrm{CP}$; nitrogen $\times 6.25)$, neutral detergent fiber (NDF), and in vitro true digestibility (IVTD). The $r^{2}$ values for validation computed over years and harvests were 0.94 and 0.95 for CP, 0.83 and 0.77 for NDF, and 0.81 and 0.73 for IVTD, for forage kochia and grass, respectively. Samples used for calibration were analyzed for nitrogen using a LECO CHN-2000 Series Elemental Analyzer (LECO Corp, St. Joseph, MI). Neutral detergent fiber and IVTD were determined following the methods of Goering and Van Soest (1970) as modified in the ANKOM procedures (Anonymous 2005a, $2005 \mathrm{~b})$. The first stage of the IVTD procedure consisted of a 48-hour in vitro fermentation in the ANKOM Daisy II incubator (ANKOM Technology Corporation, Macedon, NY). Analyses for NDF and for the second stage of the IVTD procedure were made with an ANKOM-200 Fiber Analzyer (ANKOM Technology). The IVTD procedure differs from the classic 2-stage Tilley and Terry IVDMD procedure by substitut- ing an NDF extraction for pepsin and hydrochloric acid in the second stage. This results in a more complete removal of bacterial residues and other pepsin insoluble material and generally results in a higher digestibility value.

Forage quality of the diet selected (diet preference) by cows on pasture was determined in November 2002 and January 2003 (year 1 only) using 6 ruminally cannulated cows (2 in each of the 3 pastures). Diet samples were collected using the rumen-evacuation technique (Lesperance et al. 1960). Diet samples were chilled, transported to the laboratory, and freezedried. Diet samples, as well as the alfalfa hay in both years, were analyzed for CP, NDF, and IVTD using wet chemistry as described for calibration samples above. The potential for diet preference, based upon plant nutritional quality, was further evaluated by comparing the quality of forage kochia seeds, leaves, and stems using 10 independent $1-\mathrm{m}^{2}$ samples harvested from the study site in November 2003. Samples were dried and brought to the laboratory, where seeds, leaves and stems were separated and analyzed individually for CP, NDF, and IVTD.

\section{Statistical Analyses}

Initial, final, and overall changes in cattle BW, BCS, and BF were analyzed across and within years ( 2 treatments $\times 2$ years factorial) using the MIXED procedure (SAS Institute, 1998) with pasture vs. drylot (treatments) and year as fixed effects, and pasture/pen (replication) and cows nested within treatments-year-pasture/pen considered random. Mean comparisons were made between treatments using Fisher's Protected Least Significant Difference (LSD) test at the $P=0.05$ level of probability.

Available forage yield and quality (CP, NDF, and IVTD) of the pastures were also analyzed across and within years as a mixed model with species (forage kochia vs. grass), year, and date of harvest considered fixed effects, and pasture (replication) as a random variable. Mean comparisons were made between species and among dates of harvest using Fisher's Protected LSD test at the $P=0.05$ level of probability. Diet selected by cannulated cows was also analyzed as described above with mean comparison at the $P=0.05$ level of probability between the November and January sampling dates.

\section{Economic Analysis}

Partial budgeting techniques were used to compare the 2 feeding strategies. Some costs common to both strategies, such as land costs, were excluded because they would have to be paid under either scenario. The only costs included were those that were different and associated with each strategy, i.e., fertilizer, irrigation, harvesting, etc. A partial alfalfa budget (Utah Agricultural Statistics Service 1997) was updated to 2004 to reflect current costs (Table 1). A partial budget for forage kochia/crested wheatgrass was developed using data available from recent forage kochia-crested wheatgrass pasture development and maintenance (Table 2). Data were converted into costs $\cdot \operatorname{cow}^{-1} \cdot \mathrm{d}^{-1}$ by multiplying cost $\cdot \mathrm{kg}^{-1}$ of forage by the average daily disappearance (intake plus waste) for each treatment. In addition, costs $\cdot \operatorname{cow}^{-1} \cdot \mathrm{d}^{-1}$ were also calculated substituting the NRC (1996) intake requirements for maintenance of late-gestation cattle for our disappearance rate. The range between the NRC-derived and study-derived values is 
Table 1. Partial alfalfa budget in 2004 dollars.

\begin{tabular}{lr}
\hline Item (per-hectare basis) & $\$ \cdot$ ha $^{-1}$ \\
\hline Purchases & \\
Phosphate & 84.03 \\
Metribuzin & 10.37 \\
Carbofuran & 5.46 \\
Twine & 14.13 \\
Soil test & 0.25 \\
Total purchases & 114.24 \\
Operations & \\
Fertilizer application & \\
Herbicide application & 2.91 \\
Insecticide application & 4.92 \\
Swathing & 4.92 \\
Turning & 83.51 \\
Baling (large bales) & 14.77 \\
Hauling & 89.14 \\
Irrigation & 68.76 \\
Operating interest for 6 mo at $8 \%:$ & 250.00 \\
Total operating costs & 28.48 \\
Establishment cost $\left(\$ 475.48\right.$ ha $^{-1}$ ) & 653.93 \\
$\quad$ amortized over 6 y at $8 \%$ & \\
Total listed costs $\left(\$ \cdot\right.$ ha $^{-1}$ ) & 102.85 \\
Feed available $\left(\mathrm{kg}^{-1} \mathrm{ha}^{-1}\right.$ ) & 871.02 \\
Cost $\mathrm{kg}^{-1}$ of alfalfa hay produced & 440 \\
\hline
\end{tabular}

${ }^{1}$ Calculated by dividing total costs by the estimated alfalfa hay production. The cost is equivalent to $\$ 65 \cdot \mathrm{Mg}^{-1}$ (metric ton) or $\$ 73 \cdot \mathrm{US}$ ton $^{-1}$.

reflective of potential economic savings by reducing trampling and waste.

\section{RESULTS}

\section{Cattle Performance}

Treatment and year effects were found to be highly significant for change in body condition score and backfat (Table 3). No significant treatment $\times$ year interactions were evident, suggesting consistent relative performance between treatments in both years (Table 3). Averaged over years, both feeding alfalfa and grazing forage kochia-grass pastures resulted in acceptable cattle performance, with both treatments increasing or maintaining BW, BCS, and BF (Table 4).

In year 1 , both drylot and pasture cows improved in BCS and BF; however, changes in BCS and BF were significantly higher $(P<0.05)$ for drylot cows compared to pasture cows (Table 4). Cows in drylot were offered $13.6 \mathrm{~kg}$ (30 pounds) dry matter $\cdot \mathrm{d}^{-1}$ of alfalfa hay, with very little being wasted. Nutritive value of the alfalfa hay (dry matter basis) for year 1 was approximately $18.0 \% \mathrm{CP}$, with $1.41 \mathrm{Mcal} \cdot \mathrm{kg}^{-1}$ dry matter (62\% total digestible nutrients). This exceeded NRC (1996) nutrient requirements for cows in late gestation. The experiment ended within days of the onset of parturition, with a targeted minimal BCS of 5.0 desired to ensure that cows would rebreed within an 80-day window (NRC 1996). Cows receiving alfalfa had a higher average BCS (6.0), as compared to a BCS of 5.3 for cows on forage kochia, and may have been slightly
Table 2. Partial budget for forage kochia/crested wheatgrass in 2004 dollars. ${ }^{1}$

\begin{tabular}{|c|c|}
\hline Item (per-hectare basis) & $\$ \cdot \mathrm{ha}^{-1}$ \\
\hline \multicolumn{2}{|l|}{ Establishment } \\
\hline \multicolumn{2}{|l|}{ Forage kochia seed } \\
\hline $\begin{array}{l}\text { Crested wheatgrass seeding } \\
\qquad\left(8.96 \mathrm{~kg} \cdot \mathrm{ha}^{-1} \text { at } \$ 2.75 \cdot \mathrm{kg}^{-1}\right)\end{array}$ & 24.64 \\
\hline Broadcast forage kochia seed & 24.70 \\
\hline Roll and drill grass in 1 pass & 29.64 \\
\hline Disk plow & 49.40 \\
\hline Offset disk & 34.58 \\
\hline Operating interest ( $9 \%$ for $18 \mathrm{mo})$ & 23.66 \\
\hline Total establishment costs & 198.94 \\
\hline Annualized cost (10 y at $8 \%)$ & 29.65 \\
\hline \multicolumn{2}{|l|}{ Annual maintenance costs } \\
\hline Fence repair & 4.94 \\
\hline Interest on operating cost ( $8 \%$ for $12 \mathrm{mo})$ & 0.40 \\
\hline Annualized establishment cost (10 y at $8 \%)$ & 29.65 \\
\hline Total annual costs & 34.99 \\
\hline Average feed available $\left(\mathrm{kg} \cdot \mathrm{ha}^{-1}\right)$ & 1455.5 \\
\hline Cost $\cdot \mathrm{kg}^{-1}$ of forage produced & $0.024^{2}$ \\
\hline
\end{tabular}

overconditioned to quickly return to estrus. Despite the lower BCS, cows grazing forage kochia pastures exceeded the targeted minimal BCS (5.0), thus optimizing reproductive performance.

In year 2, changes in BCS and BF were not significantly different between cows grazing forage kochia pastures and those in drylot (Table 4). Cattle on pasture maintained body condition throughout the grazing season, whereas those in drylot had significantly higher BCS in January than in November. Cows in drylot received $15.9 \mathrm{~kg}$ (35 pounds) dry matter of alfalfa hay $\cdot \mathrm{d}^{-1}$ containing $21 \% \mathrm{CP}$ and $1.41 \mathrm{Mcal} \mathrm{kg}{ }^{-1}$ dry matter, which again exceeded requirements and resulted in alfalfa-fed cows tending to hold their condition at a higher level than those on the forage kochia-grass pasture.

Though these results are not significantly different, drylot and pasture cattle lost $0.2 \mathrm{~cm}$ and $0.6 \mathrm{~cm}$ of backfat, respectively, in year 2 (Table 4). This was strikingly opposite to year 1 ; however, cattle entered the second year with approximately $300 \%$ more backfat than in year 1. Correlations of 0.29 $(P<0.062)$ and $-0.82(P<0.001)$ between initial $\mathrm{BF}$ and changes in $\mathrm{BF}$ in year 1 and 2, respectively, suggests that cattle could not maintain the high amounts of backfat during the late gestation period with the given climatic conditions and quantity and quality of feed available. Furthermore, average final BF of $0.8 \mathrm{~cm}$ in year 2 was in the range of final BF in year $1(0.7$ and $1.3 \mathrm{~cm}$ ), indicating that cows were sufficiently maintained on both alfalfa hay and forage kochia-grass pastures.

\section{Available Forage}

Available forage at the beginning of each grazing season was 1300 and $1611 \mathrm{~kg} \cdot \mathrm{ha}^{-1}$ in years 1 and 2, respectively (Table 
Table 3. Probabilities of significance for sources of variation when measuring cattle performance after grazing forage kochia-grass pastures vs. alfalfa drylot during the fall and winter of $2 \mathrm{y}$. Values less than 0.05 were considered significant.

\begin{tabular}{|c|c|c|c|}
\hline Source & Body wt $(\Delta)^{1}$ & Body condition score $(\Delta)$ & Backfat $(\Delta)$ \\
\hline & \multicolumn{3}{|c|}{ 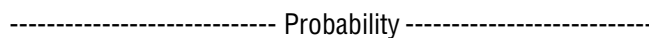 } \\
\hline Treatment & 0.077 & 0.005 & 0.008 \\
\hline Year & 0.204 & 0.092 & 0.001 \\
\hline Treatment $\times$ year & 0.198 & 0.795 & 0.464 \\
\hline
\end{tabular}

${ }^{1}$ Change that occurred from the initiation to completion of study in each year. Study period was from 05 November 2002 to 28 January 2003 in year 1, and 05 November 2003 to 22 January 2004 in year 2.

$5)$. Averaged over years, forage kochia yielded significantly $(P<0.05)$ more than crested wheatgrass, comprising approximately $70 \%$ of total available forage. Year 1 appeared to be more favorable for grass, which made up $39 \%$ of initial available forage as opposed to only $23 \%$ of total forage in year 2 .

Disappearance of available pasture forage, assumed to be cattle intake plus waste/trampling, was $23.1 \mathrm{~kg} \cdot \mathrm{cow}^{-1} \cdot \mathrm{d}^{-1}$ $(50.9 \mathrm{lb})$ in year 1 and $35.4 \mathrm{~kg} \cdot \mathrm{cow}^{-1} \cdot \mathrm{d}^{-1}(78.1 \mathrm{lb})$ in year 2 (Table 6). This was approximately $200 \%$ (year 1 ) and $300 \%$ (year 2) greater disappearance than NRC (1996) maintenance intake requirements (Table 6), indicating a high level of trampling and waste, especially in year 2 . Forage production was nearly $20 \%$ higher in year 2 than in year 1 , but by the 03 December sample date, available amounts and ratios of forage kochia to grass were nearly identical between years because of the higher rate of forage disappearance in year 2 (Table 5). By 9 January, $76 \%$ of forage had been utilized or lost in year 2 , as opposed to only $31 \%$ in the previous year. Differences in climate between the 2 years may have influenced forage disappearance, with year 1 characterized by relatively mild temperatures and lack of standing snow, vs. year 2, in which standing snow was present beginning in early December and reached depths that nearly covered all vegetation by early January. Overall, these results suggest that the colder, snow- covered environmental conditions in year 2 resulted in more trampling losses. Sampling errors caused by snow cover may have also inflated forage disappearance values for year 2 . The apparent lack of available forage and depth of snow resulted in terminating the study in year 2 at 79 days $(>76 \%$ of forage utilized or wasted) vs. terminating at 84 days $(\sim 65 \%$ of forage utilized or wasted) in year 1 , and prevented a final forage sampling.

\section{Quality of Available Forage and Selected Diet}

Averaged over years, clipped forage kochia samples had significantly $(P<0.05)$ higher (more favorable) CP, but significantly $(P<0.05)$ lower IVTD (less favorable) when compared to grass at all sampling dates (Table 5). There were relatively few differences throughout the study between forage kochia and grass for NDF (Table 5). Forage quality of both forage kochia and crested wheatgrass decreased $(P<0.05)$ as the winter progressed, presumably from selective grazing and weathering processes (Table 5).

Crude protein concentration for forage kochia was 116.5 and $76.3 \mathrm{~g} \cdot \mathrm{kg}^{-1}$ in early November and gradually declined $(P<0.05)$ throughout the grazing season to 51.1 and $44.6 \mathrm{~g} \cdot \mathrm{kg}^{-1}$ by mid to late January (study termination) in years 1 and 2, respectively (Table 5). Crude protein levels in year 2 were unexpectedly low for forage kochia and in general were about $60 \%$ of year 1 at any harvest date for both forage kochia and grass. The decline in forage quality resulted in $\mathrm{CP}$ of available whole-plant forage kochia not meeting a minimum (NRC 1996) of $70.0 \mathrm{~g} \cdot \mathrm{kg}^{-1}$ to maintain rumen function by January sample dates in year 1 and early December in year 2 . Crude protein of clipped grass samples never reached the $70.0 \mathrm{~g} \cdot \mathrm{kg}^{-1}$ level at any sample date. However, whole-plant forage quality did not preclude preferential diet selection that met minimum nutritional requirements (Table 7).

IVTD values declined and NDF values increased $(P<0.05)$ throughout the season, indicating that rate and extent of digestion of energy sources and nutrients were decreasing

Table 4. Performance measurements ( \pm standard error of mean) of mature cattle grazing forage kochia-grass pastures during the fall and winter (November through January) vs. alfalfa drylot.

\begin{tabular}{|c|c|c|c|c|c|c|c|c|c|}
\hline \multirow[b]{2}{*}{ Treatment } & \multicolumn{3}{|c|}{ Body weight } & \multicolumn{3}{|c|}{ Body condition score } & \multicolumn{3}{|c|}{ Backfat } \\
\hline & $\mid$ Initial $^{1}$ & Final $^{1}$ & $\Delta^{2}$ & Initial & Final & $\Delta$ & Initial & Final & $\Delta$ \\
\hline & \multicolumn{3}{|c|}{-------------------------kg ----------------------- } & \multicolumn{3}{|c|}{--------------------- Visual score -------------------- } & \multicolumn{3}{|c|}{ 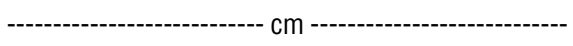 } \\
\hline \multicolumn{10}{|l|}{ 2002-2003 } \\
\hline Drylot & $616 \pm 8 y^{3}$ & $665 \pm 10 x$ & $49 \pm 7 a^{4}$ & $4.9 \pm 0.08 \mathrm{y}$ & $6.0 \pm 0.12 x$ & $1.1 \pm 0.08 \mathrm{a}$ & $0.4 \pm 0.06 y$ & $1.3 \pm 0.11 x$ & $0.9 \pm 0.06 \mathrm{a}$ \\
\hline Pasture & $615 \pm 13 x$ & $646 \pm 17 x$ & $26 \pm 8 \mathrm{a}$ & $4.8 \pm 0.09 y$ & $5.3 \pm 0.08 x$ & $0.5 \pm 0.10 \mathrm{~b}$ & $0.4 \pm 0.05 y$ & $0.7 \pm 0.05 x$ & $0.3 \pm 0.04 b$ \\
\hline \multicolumn{10}{|l|}{ 2003-2004 } \\
\hline Drylot & $603 \pm 9 y$ & $651 \pm 9 x$ & $49 \pm 5 a$ & $4.8 \pm 0.16 y$ & $5.5 \pm 0.11 x$ & $0.7 \pm 0.16 \mathrm{a}$ & $1.1 \pm 0.11 x$ & $0.9 \pm 0.08 x$ & $-0.2 \pm 0.13 a$ \\
\hline Pasture & $627 \pm 12 x$ & $630 \pm 10 x$ & $4 \pm 6 b$ & $4.9 \pm 0.16 x$ & $5.1 \pm 0.08 x$ & $0.2 \pm 0.14 \mathrm{a}$ & $1.3 \pm 0.12 x$ & $0.7 \pm 0.06 y$ & $-0.6 \pm 0.10 \mathrm{a}$ \\
\hline \multicolumn{10}{|l|}{ Mean } \\
\hline Drylot & $609 \pm 6 y$ & $658 \pm 7 x$ & $45 \pm 4 a$ & $4.9 \pm 0.09 y$ & $5.8 \pm 0.09 x$ & $0.9 \pm 0.09 a$ & $0.8 \pm 0.08 \mathrm{y}$ & $1.1 \pm 0.07 x$ & $0.3 \pm 0.11 \mathrm{a}$ \\
\hline Pasture & $621 \pm 9 x$ & $639 \pm 9 x$ & $19 \pm 6 a$ & $4.9 \pm 0.09 y$ & $5.2 \pm 0.06 x$ & $0.3 \pm 0.09 a$ & $0.9 \pm 0.10 x$ & $0.7 \pm 0.04 x$ & $-0.2 \pm 0.09 b$ \\
\hline
\end{tabular}

${ }^{1}$ Study period was from 05 November 2002 to 28 January 2003 in year 1 and from 05 November 2003 to 22 January 2004 in year 2

${ }^{2}$ Change that occurred from initiation to completion of study in each year.

${ }^{3}$ Initial and final values within a treatment and year followed by different letters ( $\mathrm{x}$ or $\mathrm{y}$ ) are significantly different at the $P<0.05$ probability level.

${ }^{4}$ Drylot and pasture change values within a year followed by different letters (a or b) are significantly different at the $P<0.05$ probability level. 
Table 5. Available forage and nutritional quality ( \pm standard error of mean) in a forage kochia-grass pasture grazed November through January by mature beef cows.

\begin{tabular}{|c|c|c|c|c|c|c|c|c|c|c|}
\hline \multirow[b]{2}{*}{ Trait $^{1}$} & \multirow[b]{2}{*}{ Date $^{2}$} & \multicolumn{3}{|c|}{ 2002-2003 } & \multicolumn{3}{|c|}{ 2003-2004 } & \multicolumn{3}{|c|}{ Mean } \\
\hline & & Forage kochia & Grass & Total & Forage kochia & Grass & Total & Forage kochia & Grass & Total \\
\hline \multirow[t]{4}{*}{$\mathrm{DM}\left(\mathrm{kg} \cdot \mathrm{ha}^{-1}\right)$} & Nov 04 & $791 \pm 165 \mathrm{a},{ }^{3} x^{4}$ & $509 \pm 57 a, x$ & 1300 & $1236 \pm 238 a, x$ & $375 \pm 47 a, y$ & 1611 & $1013 \pm 147 a, x$ & $442 \pm 37 \mathrm{a}, \mathrm{y}$ & 1455 \\
\hline & Dec 03 & $809 \pm 143 a, x$ & $404 \pm 60 \mathrm{a}, \mathrm{y}$ & 1213 & $775 \pm 125 a b, x$ & $313 \pm 32 \mathrm{a}, \mathrm{y}$ & 1107 & $797 \pm 94 a b, x$ & $359 \pm 34 \mathrm{a}, \mathrm{y}$ & 1156 \\
\hline & Jan 09 & $755 \pm 117 \mathrm{a}, \mathrm{x}$ & $146 \pm 23 b, y$ & 901 & $352 \pm 90 b, x$ & $56 \pm 9 b, y$ & 418 & $545 \pm 78 b, x$ & $101 \pm 14 b, y$ & 646 \\
\hline & Jan 28 & $277 \pm 64$ b, $x$ & $184 \pm 69 \mathrm{~b}, \mathrm{x}$ & 461 & & & & & & \\
\hline \multirow[t]{4}{*}{$\mathrm{CP}\left(\mathrm{g} \cdot \mathrm{kg}^{-1}\right)$} & Nov 04 & $116.5 \pm 8.7 \mathrm{a}, \mathrm{x}$ & $66.7 \pm 1.9 \mathrm{a}, \mathrm{y}$ & & $76.3 \pm 7.7 \mathrm{a}, \mathrm{x}$ & $40.0 \pm 1.2 \mathrm{a}, \mathrm{y}$ & & $96.2 \pm 6.5 \mathrm{a}, \mathrm{x}$ & $53.4 \pm 2.2 \mathrm{a}, \mathrm{y}$ & \\
\hline & Dec 03 & $69.0 \pm 5.5 \mathrm{~b}, \mathrm{x}$ & $60.9 \pm 4.0 \mathrm{a}, \mathrm{x}$ & & $45.8 \pm 1.8 \mathrm{~b}, \mathrm{x}$ & $37.1 \pm 1.3 \mathrm{a}, \mathrm{y}$ & & $57.5 \pm 3.2 \mathrm{~b}, \mathrm{x}$ & $39.0 \pm 2.6 \mathrm{~b}, \mathrm{y}$ & \\
\hline & Jan 09 & $50.9 \pm 2.9 c, x$ & $44.8 \pm 1.8 \mathrm{~b}, \mathrm{x}$ & & $44.6 \pm 2.2 \mathrm{~b}, \mathrm{x}$ & $30.6 \pm 1.2 \mathrm{~b}, \mathrm{y}$ & & $47.9 \pm 1.9 \mathrm{~b}, \mathrm{x}$ & $37.7 \pm 1.6 \mathrm{c}, \mathrm{y}$ & \\
\hline & Jan 28 & $51.1 \pm 5.5 \mathrm{c}, \mathrm{x}$ & $48.7 \pm 1.6 \mathrm{~b}, \mathrm{x}$ & & & & & & & \\
\hline \multirow[t]{4}{*}{$\operatorname{NDF}\left(g \cdot \mathrm{kg}^{-1}\right)$} & Nov 04 & $511.1 \pm 14.9 \mathrm{c}, \mathrm{y}$ & $619.1 \pm 6.1 \mathrm{~b}, \mathrm{x}$ & & $598.4 \pm 14.2 b, x$ & $597.2 \pm 2.8 \mathrm{c}, \mathrm{x}$ & & $555.0 \pm 12.3 \mathrm{c}, \mathrm{y}$ & $607.5 \pm 3.5 \mathrm{c}, \mathrm{x}$ & \\
\hline & Dec 03 & $602.2 \pm 11.9 \mathrm{~b}, \mathrm{x}$ & $625.7 \pm 11.1 \mathrm{~b}, \mathrm{x}$ & & $665.5 \pm 6.3 \mathrm{a}, \mathrm{x}$ & $629.1 \pm 2.9 \mathrm{~b}, \mathrm{x}$ & & $633.6 \pm 8.0 \mathrm{~b}, \mathrm{x}$ & $627.4 \pm 4.9 \mathrm{~b}, \mathrm{x}$ & \\
\hline & Jan 09 & $655.5 \pm 7.2 \mathrm{a}, \mathrm{x}$ & $664.3 \pm 12.1 \mathrm{a}, \mathrm{x}$ & & $681.9 \pm 6.2 \mathrm{a}, \mathrm{x}$ & $642.2 \pm 4.7 \mathrm{a}, \mathrm{y}$ & & $667.2 \pm 5.2 \mathrm{a}, \mathrm{x}$ & $653.5 \pm 5.6 \mathrm{a}, \mathrm{x}$ & \\
\hline & Jan 28 & $655.4 \pm 10.6 \mathrm{a}, \mathrm{x}$ & $668.3 \pm 8.0 \mathrm{a}, \mathrm{x}$ & & & & & & & \\
\hline \multirow[t]{4}{*}{ IVTD $\left(\mathrm{g} \cdot \mathrm{kg}^{-1}\right)$} & Nov 04 & $576.0 \pm 20.1 \mathrm{a}, \mathrm{y}$ & $635.9 \pm 6.1 \mathrm{a}, \mathrm{x}$ & & $502.5 \pm 19.1 \mathrm{a}, \mathrm{y}$ & $661.3 \pm 6.2 \mathrm{a}, \mathrm{x}$ & & $538.6 \pm 14.9 \mathrm{a}, \mathrm{y}$ & $649.8 \pm 4.7 \mathrm{a}, \mathrm{x}$ & \\
\hline & Dec 03 & $466.5 \pm 16.8 b, y$ & $646.2 \pm 10.8 \mathrm{a}, \mathrm{x}$ & & $422.7 \pm 6.4 \mathrm{~b}, \mathrm{y}$ & $657.1 \pm 8.4 \mathrm{a}, \mathrm{x}$ & & $445.3 \pm 8.9 b, y$ & $654.2 \pm 6.7 \mathrm{a}, \mathrm{x}$ & \\
\hline & Jan 09 & $399.2 \pm 8.7 \mathrm{c}, \mathrm{y}$ & $574.0 \pm 15.4 \mathrm{~b}, \mathrm{x}$ & & $385.8 \pm 6.9 \mathrm{c}, \mathrm{y}$ & $594.4 \pm 12.1 \mathrm{~b}, \mathrm{x}$ & & $392.7 \pm 5.7 \mathrm{c}, \mathrm{y}$ & $583.2 \pm 9.5 \mathrm{~b}, \mathrm{x}$ & \\
\hline & Jan 28 & $387.5 \pm 16.1 \mathrm{c}, \mathrm{y}$ & $573.1 \pm 11.3 b, x$ & & & & & & & \\
\hline
\end{tabular}

${ }^{1} \mathrm{DM}$ indicates dry matter; CP, crude protein; NDF, neutral detergent fiber; and IVTD, in vitro true digestibility.

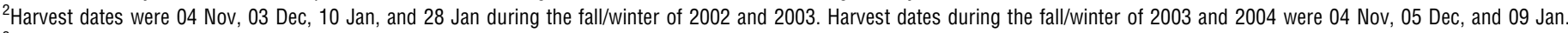

${ }^{3}$ Values down columns within traits with different letters $(a, b)$ are significantly different at the $P<0.05$ probability level.

${ }^{4}$ Values across rows within years with different letters $(x, y)$ are significantly different at the $P<0.05$ probability level.

(Table 5). Grass had consistently higher $(P<0.05)$ IVTD (digestibility) across years and sampling dates. On the other hand, there was very little difference between grass and forage kochia for NDF when comparing individual sample dates (Table 5). Exceptions included lower NDF for forage kochia at 04 November in year 1 , and vice versa, lower NDF for grass at 09 January in year 2. The difference in IVTD at similar NDF levels was probably caused by the higher lignin levels of the forage kochia vs. the grass species.

The quality of cow diets based on the preference study (year 1 only) was always higher than the quality of the available forage (Tables 5 and 7). This was to be expected because grazing livestock normally select a diet that is higher in nutritional value than the average of total available forage. Diet quality declined $(P<0.05)$ from November to January (Table 7) for CP and NDF, in correspondence to reductions in quality of available forage. However, despite the rather dramatic decline in available forage quality from November to January, January diets still had adequate crude protein to support ruminal digestion of forage $\left(70.0 \mathrm{~g} \cdot \mathrm{kg}^{-1}\right)$. Additionally, diets were approximately $60 \%$ digestible, which should be adequate to meet requirements of nonlactating cows in mid to late gestation. Potential existed for nutritionally based selective grazing, with forage kochia plant parts differing significantly $(P<0.05)$ for all quality traits with CP values of 190.6, 123.2, and $55.1 \mathrm{~g} \cdot \mathrm{kg}^{-1}$; NDF values of $393.3,474.8$, and 626.3 $\mathrm{g} \cdot \mathrm{kg}^{-1}$; and IVTD values of $741.2,653.9$, and $426.6 \mathrm{~g} \cdot \mathrm{kg}^{-1}$ for seed, leaves, and stems, respectively.

Table 6. Comparison of estimated $\operatorname{cost} \cdot \operatorname{cow}^{-1} \cdot d^{-1}$ for feeding alfalfa hay in drylot vs. grazing forage kochia-crested wheatgrass pastures, 2004 dollars. $^{1}$

\begin{tabular}{|c|c|c|c|c|c|}
\hline \multirow[b]{2}{*}{ Feeding treatment } & \multirow[b]{2}{*}{ Year } & \multicolumn{2}{|c|}{ Study forage disappearance ${ }^{2}$} & \multicolumn{2}{|c|}{ NRC maintenance intake ${ }^{3}$} \\
\hline & & $\begin{array}{c}\text { Dry matter } \\
\left(\mathrm{kg} \cdot \operatorname{cow}^{-1} \cdot \mathrm{d}^{-1}\right)\end{array}$ & $\$ \cdot \operatorname{cow}^{-1} \cdot d^{-1}$ & $\begin{array}{c}\text { Dry matter } \\
\left(\mathrm{kg} \cdot \operatorname{cow}^{-1} \cdot \mathrm{d}^{-1}\right)\end{array}$ & $\$ \cdot \operatorname{cow}^{-1} \cdot d^{-1}$ \\
\hline \multirow[t]{3}{*}{ Alfalfa hay } & 1 & 13.6 & 0.87 & 13.0 & 0.83 \\
\hline & 2 & 15.9 & 1.02 & 13.1 & 0.84 \\
\hline & Mean & 14.8 & 0.94 & 13.0 & 0.83 \\
\hline \multirow[t]{3}{*}{ Kochia-grass pasture } & 1 & 23.1 & 0.55 & 12.4 & 0.30 \\
\hline & 2 & 35.4 & 0.85 & 12.6 & 0.30 \\
\hline & Mean & 29.3 & 0.70 & 12.5 & 0.30 \\
\hline
\end{tabular}

${ }^{1}$ Calculated by taking the average disappearance/use $(\mathrm{kg}) \cdot \operatorname{cow}^{-1} \cdot \mathrm{d}^{-1}$ times the cost $\cdot \mathrm{kg}^{-1}$ of forage $\left(\$ 0.064 \cdot \mathrm{kg}^{-1}\right.$ alfalfa hay and $\$ 0.024 \cdot \mathrm{kg}^{-1} \mathrm{kochia}-\mathrm{grass}$ pasture $)$.

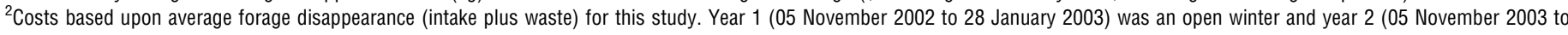
22 January 2004) was a snow-covered winter.

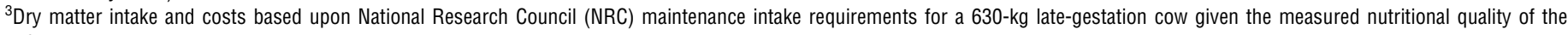
forage. 


\section{Economics of Grazing Forage Kochia-Grass Pastures vs. Drylot Feeding}

Averaged over the 2 years, feeding costs of cows grazing forage kochia-grass pastures were lower by $\$ 0.24 \cdot \mathrm{cow}^{-1} \cdot \mathrm{d}^{-1}$ compared to the drylot alfalfa-fed cows (Table 6). Feed cost differences between the 2 feeding methods were $\$ 0.32$ and $\$ 0.17 \cdot \operatorname{cow}^{-1} \cdot \mathrm{d}^{-1}$ in years 1 and 2 , respectively. The reduced savings in year 2 is a reflection of greater forage disappearance in the pastures (Table 6), probably caused by increased snow cover and trampling losses.

\section{DISCUSSION}

We found that forage kochia-grass pastures provide adequate nutrition for extending livestock grazing into the fall and winter. As nearly as we can tell, this is the first replicated, peer-reviewed research reporting livestock performance on forage kochia. Our findings were similar to previous reports that palatable shrubs and crested wheatgrass complement each other nutritionally and, when grown in a mix, can meet nutritional requirements of late-gestation ruminants (Cook 1972; Otsyina et al. 1982; Gade and Provenza 1986; McKell et al. 1990). Cook (1972) reported that during the winter, shrubs meet gestation requirements for protein, but are low in energy, whereas mature grasses are deficient in protein, but maintain adequate energy levels. Cook et al. (1951) reported that on winter rangelands, mature grasses contained higher levels of energy-producing digestible cellulose than associated shrubs. With few exceptions, the forage kochia had equal or lower NDF but higher acid detergent fiber (ADF) $(P<0.05$, data not shown) than the grass samples. The higher ADF in the forage kochia is expected, because most shrubs have higher nondigestible lignin levels than grasses. Lower NDF is typically considered more desirable, suggesting more cell solubles; however, higher NDF in the grass samples would be in agreement with Cook et al. (1951) because it is reflective of higher levels of potentially digestible fiber, including cellulose and hemicellulose in the cell walls.

In both years, initial CP levels for forage kochia were above the $70 \mathrm{~g} \cdot \mathrm{kg}^{-1}$ requirement for late-gestation beef cattle (NRC 1996), but after 1 month of grazing, the CP level in residual forage kochia had fallen below this minimum level (Table 5). This agrees with findings by McKell et al. (1990) wherein CP levels in a forage kochia-crested wheatgrass pasture fell from approximately $90 \mathrm{~g} \cdot \mathrm{kg}^{-1}$ to $55 \mathrm{~g} \cdot \mathrm{kg}^{-1}$ after 13 days of confined grazing by sheep. However, in their study (McKell et al. 1990) and our evaluation, contents from diet samples were higher in CP and digestibility than in the total available biomass, meeting minimum ruminant requirements. They suggested that forage kochia contained less woody stems than their comparison of winterfat (Krascheninnikovia lanata [Pursh] A. D. J. Meeuse \& Smit), allowing greater opportunity for selective grazing. Cook et al. (1953) reported that sheep grazed tender stems and leaves, changing CP levels of available shrub biomass from 10 to $6 \mathrm{~g} \cdot \mathrm{kg}^{-1}$. Relative to our results, Davenport (2005) observed that cattle selectively grazed portions of forage kochia stems containing seeds. They then went on to graze upper stems and leaves. Davis and Welch (1985) reported that in November, upper seed-bearing forage kochia
Table 7. Forage quality of diet selected by ruminally cannulated cows grazing forage kochia-crested wheatgrass pastures in November 2002 and January 2003. ${ }^{1}$

\begin{tabular}{lcc}
\hline Trait & November 2002 & January 2003 \\
\hline CP $\left(\mathrm{g} \cdot \mathrm{kg}^{-1}\right)$ & $12.6 \mathrm{a}$ & $7.3 \mathrm{~b}$ \\
$\operatorname{NDF}\left(\mathrm{g} \cdot \mathrm{kg}^{-1}\right)$ & $53.8 \mathrm{~b}$ & $64.6 \mathrm{a}$ \\
IVTD $\left(\mathrm{g} \cdot \mathrm{kg}^{-1}\right)$ & $62.2 \mathrm{a}$ & $60.1 \mathrm{a}$ \\
\hline
\end{tabular}

${ }^{1}$ Values across rows with different letters are significantly different at the $P<0.05$ probability level. CP indicates crude protein; NDF, neutral detergent fiber; and IVTD, in vitro true digestibility.

stems had higher levels of CP $\left(107 \mathrm{~g} \cdot \mathrm{kg}^{-1}\right)$ than the remaining lower, leaf-bearing part of the stems $\left(86 \mathrm{~g} \cdot \mathrm{kg}^{-1}\right)$. This is in agreement with our study; we saw a dramatic decline in CP values of $190.6,123.2$, and $55.1 \mathrm{~g} \cdot \mathrm{kg}^{-1}$ for seed, leaves, and stems, respectively. We also observed a similar reduction in digestibility with a $43 \%$ decrease in IVTD of forage kochia stems compared to seeds. Therefore, we conclude that preferential grazing, and relative declining proportion of quality from seeds to lower stems, accounted for the reduction in forage quality of available forage kochia. Jensen et al. (2002) reported that weathering did not change forage quality from November through January in crested wheatgrass, suggesting that preferential grazing also reduced the quality of the grass component in our study.

Our year 1 November forage kochia CP of $116 \mathrm{~g} \cdot \mathrm{kg}^{-1}$ was similar to the November CP of $140 \mathrm{~g} \cdot \mathrm{kg}^{-1}$ reported by Davis (1979) (whole plants; Washington), and Davis and Welch's (1985) November CP of $107 \mathrm{~g} \mathrm{~kg}^{-1}$ (upper stems; Utah), and was in near-perfect agreement with early October CP values of $115 \mathrm{~g} \cdot \mathrm{kg}^{-1}$ reported by Davenport (2005; whole plants; approximately $16 \mathrm{~km}$ from our study). The low initial CP of 76 $\mathrm{g} \cdot \mathrm{kg}^{-1}$ for forage kochia in year 2 was unexpected and difficult to explain. One possibility may be that the discrepancy resulted from the increased biomass in year $2(150 \%$ more than year 1$)$ being mostly stems with little increase in relative seed production. However, during the same year Davenport (2005) reported CP value of $111 \mathrm{~g} \cdot \mathrm{kg}^{-1}$ and less biomass from forage kochia growing about $16 \mathrm{~km}$ to the west of our study site. Whatever the cause, the ability of the cows to maintain BCS suggests that they were able to preferentially select higherquality diets than present in the available biomass, even with snow cover. Because of preferential grazing by cows in our study, it is impossible to compare our January forage kochia CP levels (average $47.9 \mathrm{~g} \cdot \mathrm{kg}^{-1}$ ) with published reports ranging from 103 to $75 \mathrm{~g} \cdot \mathrm{kg}^{-1}$ on stockpiled plants (Davis 1979; Davis and Welch 1985; Koch 2002). Our crested wheatgrass average November CP value of $53.4 \mathrm{~g} \cdot \mathrm{kg}^{-1}$ is higher than the $32 \mathrm{~g} \cdot \mathrm{kg}^{-1}$ reported by Jensen et al. (2002), and is close to the August CP of $53 \mathrm{~g} \cdot \mathrm{kg}^{-1}$ reported by Knipfel (1977). We surmise that limited early-fall regrowth of crested wheatgrass, stimulated by late-summer rains, is probably necessary to observe CP values as high as $50 \mathrm{~g} \cdot \mathrm{kg}^{-1}$, and may not always occur.

Empirical data suggests that forage kochia can withstand higher utilization and probably has greater grazing tolerance than most common rangeland shrubs (Waldron et al. 2005). In our study we exceeded $65 \%$ and $75 \%$ utilization in years 1 and 2 , respectively, which is much higher than the standard 
USDA-NRCS recommendation of $60 \%$ winter utilization of grass-shrub rangelands (T. Simper, NRCS, personal communication, 02 March 2005). The decreased forage availability corresponded with decreases in forage quality, which we believe was caused by preferential diet selection. Despite the drop in available forage and quality, the cattle had access to adequate forage to select a diet that met or exceeded their nutrient requirements. However, it appears that cows should be moved to new pastures or drylot when residual forage of forage kochiagrass pastures reaches $60 \%$ to $65 \%$ utilization to ensure that diet quality does not fall below maintenance requirements.

Averaged over years, change in BW and BCS did not differ significantly between cattle on forage kochia-grass pastures vs. drylot alfalfa-fed cattle. Cows grazing forage kochia and crested wheatgrass maintained or increased $\mathrm{BW}$ and maintained or improved BCS each year. The average final BCS of 5.2 would be considered optimum condition for cows as they entered parturition (Freeze et al. 1999). The average BF of pasture-fed cows of $0.70 \mathrm{~cm}$ is greater than the 0.5 to $0.6 \mathrm{~cm}$ suggested by Freeze et al. (1999) as physiologically and economically most efficient for overwintering cows. This suggests that the nutritional quality of our pastures was adequate and perhaps in excess of winter maintenance requirements. In our study, cows on both pasture and drylot lost BF in year 2 (Table 4); however, BF loss was not significantly different between the 2 feeding treatments, suggesting that cows came off summer ranges overconditioned, and does not reflect that pastures had inadequate nutrient quality.

These results are in sharp contrast to most fall-winter grazing evaluations of standing forage. Willms et al. (1993) found that cows grazing fescue prairies during the fall and winter finished with $0.35 \mathrm{~cm}$ of $\mathrm{BF}$ (less than the target of $0.5 \mathrm{~cm}$ ), and concluded that feed supplementation was needed to achieve optimal condition at calving. Cattle grazing mixed grass prairies during the fall and winter lost BW and BCS $(-0.5)$ finishing with a suboptimal BCS of 4.6, which was significantly lower than the BCS (5.4) of cows receiving highprotein alfalfa cube supplements (Cochran et al. 1986). Villalobos et al. (1997) found similar results when wintering cows on the sandhills rangeland of Nebraska, where their cows lost BW and 1.2 points of BCS, ending with a final BCS of 4.7. Their results also showed that supplementation with highprotein sources of soybean meal or harvested hay was necessary to maintain gestating beef cows on winter ranges. Hitz and Russell (1998) showed improved ability to maintain optimal BCS of cattle wintering on stockpiled irrigated tall fescuealfalfa pastures in Iowa, but unlike our study, in their study cows were offered harvested hay when BCS went below 5 or when heavy snow impeded grazing, and were moved to new paddocks each time $60 \%$ of forage was removed. Similarly, Adams et al. (1994) were able to maintain optimal condition on cattle winter grazing sandhills rangeland by feeding every other day with a $36 \%$ CP supplement or grazing irrigated meadow and supplementing during snow and subzero temperatures. The contrast between our results and these previous reports suggest that forage kochia provided the nutritional quality (especially $\mathrm{CP})$, and perhaps forage quantity, missing from the stockpiled grass in these studies. In one preliminary study, Koch (2002) reported that cattle improved 2 points in BCS when grazing forage kochia in Wyoming during the winter; however, they also supplemented each day with a high-energy and moderate$\mathrm{CP}$ grain supplement, making it difficult to compare with our results.

Economic analysis showed $26 \%$ less cost $\cdot \operatorname{cow}^{-1} \cdot \mathrm{d}^{-1}$ wintering on forage kochia-grass pastures compared to drylot feeding (Table 6). Given the assumptions noted in Tables 1 and 2 , we estimated a cost of $\$ 0.70 \cdot \operatorname{cow}^{-1} \cdot \mathrm{d}^{-1}$ grazing forage kochia vs. $\$ 0.94 \cdot \operatorname{cow}^{-1} \cdot \mathrm{d}^{-1}$ feeding harvested alfalfa hay. This is in line with the rule of thumb of $\$ 0.25 \cdot \operatorname{cow}^{-1} \cdot \mathrm{d}^{-1}$ savings for extending the grazing season as reported by McCartney et al. (2004). Given that the cattle on pasture were in optimum condition for calving and breeding (Freeze et al. 1999), this represents a substantial economic benefit, even without accounting for labor and machinery costs to feed alfalfa hay. Consequently, economic benefits may be underestimated because of normal labor, facilities, and machinery costs associated with drylot feeding. Another consideration is that forage kochia is adapted and often planted on salt desert shrub and sagebrush-grass rangelands that may be infested with cheatgrass, have alkali soils, and/or have other conditions that prevent production of alfalfa and other crops. Increased productivity and resulting higher carrying capacity from forage kochia and adapted grasses in these environments further increases the economic benefit. In addition, we calculated costs based upon our disappearance rate of available forage (Table 6). This rate resulted in much higher costs than the estimated grazing cost of $\$ 0.30 \cdot \mathrm{cow}^{-1} \cdot \mathrm{d}^{-1}$ when estimates are based only on NRC (1996) maintenance intake requirements (Table 6). This suggests that grazing management that reduces trampling, or locations with little snow cover (such as in year 1), could result in even greater economic benefits.

\section{MANAGEMENT IMPLICATIONS}

Our research supports Cook's (1972) conclusion that a mix of shrubs or semishrubs and grasses on semidesert rangelands can provide a balanced nutritional diet for wintering livestock.

Forage kochia appears to complement crested wheatgrass, and probably most other cool-season Triticeae grasses, and could provide the protein source needed in such mixes. Our observations were in agreement with those of Gade and Provenza (1986), who reported that shrubs, unlike crested wheatgrass, continued to be available for grazing during snow periods. However, forage kochia's semishrub nature, and the short stature of 'Immigrant,' the only currently available cultivar, would make forage kochia less available than more woody shrubs as snow accumulates. Forage kochia has advantages over common range shrubs, including lower lignin content than winterfat (McKell et al. 1990), higher cattle preference than winterfat (Davenport 2005), and unlike sagebrush and rabbitbrush, appears to provide the minimal gestational ruminant requirement for digestible protein (Otsyina et al. 1982). Also, unlike many of these shrubs, it is not known to contain antiquality defense chemicals, such as terpenoids. In addition, forage kochia is relatively easy to establish in degraded and cheatgrass-infested rangelands, in comparison to most other adapted shrubs (Monaco et al. 2003).

In summary, forage kochia is a nutritious perennial that is well adapted to the Intermountain West region of the US. There 
are tremendous potential advantages for beef producers in using it as a roughage source for grazing beef cows during late fall and early winter as an alternative to feeding harvested forage. We have shown that wintering cows on forage kochiagrass pastures can reduce costs by at least $\$ 0.24 \cdot \operatorname{cow}^{-1} \cdot \mathrm{d}^{-1}$ over drylot feeding, thereby increasing the potential viability and sustainability of beef production in the western US. Assuming a 100-day winter feeding period, a producer could realize a $\$ 24.00 \cdot \mathrm{cow}^{-1}$ savings by grazing stockpiled forage kochia and grass vs. drylot feeding, thus lowering cow-calf production annual costs by approximately $10 \%$ (USDA's estimated cow-calf production annual operating costs for the western US is $\$ 232 \cdot \mathrm{cow}^{-1}$ [Short 2001]). These savings are based on a maintenance feeding program and assume that cattle enter the fall/winter already in good body condition. Additional research is needed to compare forage kochia-grass pastures to the common practice of wintering on grass pastures with or without protein supplements. Overall, we conclude that forage kochia-wheatgrass rangelands could be an important management option to reduce winter feed costs and improve livestock ranching profitability.

\section{ACKNOWLEDGMENTS}

We gratefully acknowledge the technical assistance of Burke Davenport, Clint Stonecipher, Brett Bowman, Deane Harrison, Lynn Larsen, Ron Reed, and Howard Horton. We thank the USDA Farm Service Agency, State of Utah and Box Elder County offices, for allowing us to conduct this research on CRP fields, and the USDA Natural Resources Conservation Service for assistance in mapping out fields and estimating carrying capacity. We are especially thankful for Robert and Ben Adams of the Salt Wells Cattle Co. for allowing and helping us to conduct this research on their ranch.

\section{LITERATURE CITED}

Adams, D. C., R. T. Clark, S. A. Coady, J. B. Lamb, and M. K. Nielsen. 1994. Extended grazing systems for improving economic returns from Nebraska sandhills cow/calf operations. Journal of Range Management 47:258-263.

[Anonymous]. 2005a. Neutral detergent fiber in feeds: Filter bag technique. ANKOM Technology Corporation, Macedon, NY. Available at http://www.ankom. com/. Accessed 15 February 2006.

[Anonymous]. 2005b. In Vitro True Digestibility using the DAISY" incubator. ANKOM Technology Corporation, Macedon, NY. Available at http://www.ankom. com/. Accessed 15 February 2006.

Balyan, G. A. 1972. Prostrate summer cypress and its culture in Kirghizia. Isdatel'stvo, Frunze, Kirgizistan. Translated from Russian, 1979. Published for the U.S. Department of Agriculture and the National Science Foundation by the Al Ahram Center for Scientific Translation; Springfield, VA: Available from National Technical Information Service. 294 p.

Blauer, A. C., E. D. McArthur, R. Stevens, and S. D. Nelson. 1993. Evaluation of roadside stabilization and beautification plantings in south-central Utah. Ogden, UT: USDA-FS. Res. Pap. INT-462. 65 p.

Clements, C. D., K. J. Gray, and J. A. Young. 1997. Forage kochia: to seed or not to seed. Rangelands 19:29-31.

Cochran, R. C., D. C. Adams, P. O. CurRie, and B. W. Knapp. 1986. Cubed alfalfa hay or cottonseed meal-barley as supplements for beef cows grazing fall-winter range. Journal of Range Management 39:361-364.

Cook, C. W. 1972. Comparative nutritive values of forbs, grasses, and shrubs. In: C. M. McKell, P. J. Blaisdell, and P. R. Goodin [EDS.]. Wildland shrubs. Their biology and utilization. Ogden, UT: USDA Forest Serv. Gen. Tech. Rep. INT-1. p 303-310.

Cook, C. W., L. A. Stoddart, and L. E. Harris. 1951. Measuring consumption and digestibility of winter range plants by sheep. Journal of Range Management 4:335-346.

Cook, C. W., L. A. Stoddart, ANd L. E. HaRRIs. 1953. Effects of grazing intensity upon the nutritive value of range forage. Journal of Range Management 6:51-54.

DAVENPORT, B. W. 2005. Utilization of forage kochia (Kochia prostrata) and its relation to forage quality and morphological characteristics [thesis]. Logan, UT: Utah State University. $65 \mathrm{p}$.

Davis, A. M. 1979. Forage quality of prostrate kochia compared with 3 browse species. Agronomy Journal 71:822-824.

Davis, J. N., AND B. L. WelCH. 1985. Winter preference, nutritive value, and other range use characteristics of Kochia prostrata schrad. Great Basin Naturalist 45:778-782.

Francols, L. E. 1976. Salt tolerance of prostrate summer cypress. Agronomy Journal 68:455-456.

Freeze, B. S., W. D. Willms, and L. Rode. 1999. Economics of maintaining cow condition on fescue prairie in winter. Journal of Range Management 52 : 113-119.

Goering, H. K., and P. J. Van Soest. 1970. Forage fiber analysis (apparatus, reagents, procedures, and some applications). Washington, DC: US Government Printing Office. USDA-ARS Agric. Handb. 379.

Gade, A. E., and F. D. Provenza. 1986. Nutrition of sheep grazing crested wheatgrass versus crested wheatgrass-shrub pastures during winter. Journal of Range Management 39:527-530.

Harrison, R. D., B. L. Waldron, K. B. Jensen, R. Page, T. A. Monaco, W. H. Horton, and A. J. Palazzo. 2002. Forage kochia helps fight range fires. Rangelands 24(5):3-7.

Harrison, R. D., N. J. Chatterton, B. L. Waldron, B. W. Davenport, A. J. Palazzo, W. H. HoRton, and K. H. Asay. 2000. Forage kochia-its compatibility and potential aggressiveness on Intermountain rangelands. Logan, UT: Utah State University. Utah Ag. Exp. Sta. Res. Rpt. 162.66 p. Available at: http://www.usu.edu/ forage/report.htm. Accessed 24 June 2005.

HathaWay, Ronald. 2003. Alternative winter nutritional management strategies. Moscow, ID: University of Idaho, Ag Publications. Western Beef Resource Committee, Cow-Calf Management Guide CL314.

Hitz, A. C., And J. R. Russell. 1998. Potential of stockpiled perennial forages in winter grazing systems for pregnant beef cows. Journal of Animal Science 76:404-415.

Houseal, G. A., AND B. E. OLSON. 1996. Nutritive value of live and dead components of two bunchgrasses. Canadian Journal of Animal Science 76:555-562.

Jefferson, P. G., W. P. McCaughey, K. May, J. Woosaree, and L. McFarlane. 2004. Forage quality of seeded native grasses in the fall season on the Canadian Prairie Provinces. Canadian Journal of Plant Science 84:503-509.

Jensen, K. B., D. A. Johnson, K. H. Asay, and K. C. Olson. 2002. Seasonalaccumulated growth and forage quality of range grasses for fall and winter grazing. Canadian Journal of Plant Science 82:329-336.

$\mathrm{KoCH}$, D. 2002. Kochia-a forage with winter grazing potential. University of Wyoming Extension. Available at http://www.wyorange.net/Drought/ kochia.html. Accessed 24 June 2005.

KNIPFEL, J. E. 1977. Nutritional adequacy of mature Altai wild ryegrass and crested wheatgrass, or of alfalfa-wheat straw mixtures for the pregnant ewe. Canadian Journal of Animal Science 57:405-410.

Lesperance, A. L., V. R. Bohman, and D. W. Marble. 1960. Development of techniques for evaluating grazed forage. Journal of Dairy Science 43:682-689.

Maserus, M. 1992. High stature grasses for winter grazing. Journal of Soil and Water Conservation 47:224-225.

McArthur, E. D., B. C. Guinta, and A. P. Plummer. 1974. Shrubs for restoration of depleted ranges and disturbed areas. Utah Science 34:28-33.

McArthur, E. D., A. C. Blauer, and R. Stevens. 1990. Forage kochia competition with cheatgrass in central Utah. In: D. E. McArthur, E. M. Romney, S. D. Smith, and P. T. Tueller [comps.]. Proceedings-Symposium on Cheatgrass Invasion, Shrub Dieoff, and Other Aspects of Shrub Biology and Management. USDA Forest Serv. Gen. Tech. Rep. INT-276. Ogden, UT. p 56-65.

McArthur, E. D., S. C. Sanderson, and J. N. Davis. 1996. Adaptation of forage kochia accessions across an environmental gradient in Rush Valley, Utah. Arid Soil Research and Rehabilitation 10:125-138. 
McCartney, D., J. A. Basarab, E. K. Okine, V. S. Baron, and A. J. Depalme. 2004. Alternative fall and winter feeding systems for spring calving beef cows. Canadian Journal of Animal Science 84:511-522.

McKell, C. M., R. M. Otsyina, And J. MalecheK. 1990. Diets of sheep grazing forage kochia and winterfat mixed grass pastures in late fall. In: D. E. McArthur E. M. Romney, S. D. Smith, and P. T. Tueller [comps.]. Proceedingssymposium on cheatgrass invasion, shrub dieoff, and other aspects of shrub biology and management. Ogden, UT: USDA Forest Service. Gen. Tech. Rep. INT-276. p 310-316.

Monaco, T. A., B. L. Waldron, R. L. Newhall, and W. H. Horton. 2003. Reestablishing perennial vegetation in cheatgrass monocultures. Rangelands 25(2):26-29.

Nemati, Nasser. 1977. Comparative palatability of Atriplex canescens. Journal of Range Management 20(5):368-369.

[NRC] National Research Council. 1996. Nutrient requirements of beef cattle. 7th ed. Washington, DC: National Academy Press.

OLSON, K. C. 2005. Range management for efficient reproduction. Journal of Animal Science 83(E. Suppl):E107-E116.

Otsyina, R., C. M. McKell, AND G. Van Epps. 1982. Use of range shrubs to meet nutrient requirements of sheep grazing on crested wheatgrass during fall and early winter. Journal of Range Management 35:751-753.

Perry, R. C., L. R. Corah, R. C. Cochran, W. E. Beal, J. S. Stevenson, J. E. Minton, D. D. Simms, and J. R. Brethour. 1991. Influence of dietary energy on follicular development, serum gonadotropins, and first postpartum ovulation in suckled beef cows. Journal of Animal Science 69:3762-3773.

Romo, J. T., AND M. R. HAfERKAMP. 1987. Forage kochia germination response to temperature, water stress, and specific ions. Agronomy Journal 79:27-30.

SAS InSTITUTE Inc. 1998. SAS/STAT user's guide. Cary, NC: SAS Institute Inc.

SHORT, S. D. 2001. Characteristics and production costs of US cow-calf operations. Statistical Bulletin Number 974-3. Washington, DC: US Department of Agriculture, Economic Research Service. 26 p.

Stevens, R., and E. D. McArthuR. 1990. 'Immigrant' forage kochia competition with halogeton following various seeding techniques. In: D. E. McArthur, E. M. romney, S. D. Smith, and P. T. Tueller [comps.]. Proceedings-symposium on cheatgrass invasion, shrub dieoff, and other aspects of shrub biology and management. USDA Forest Serv. Gen. Tech. Rep. INT-276. Ogden, UT. p. $175-180$.

Stevens, R., K. R. Jorgensen, E. D. McArthur, and J. N. Davis. 1985. 'Immigrant' forage kochia. Rangelands 7:22-23.

Utah Agricultural Statistics Service. 1997. Utah agricultural statistics and Utah department of agriculture and food annual report. Salt Lake City, UT: Utah Dept. of Agriculture and Food.

Villalobos, G., D. C. Adams, T. J. Klopfenstein, J. T. Nichols, and J. B. Lamb. 1997. Grass hay as a supplement for grazing cattle I. Animal performance. Journal of Range Management 50:351-356.

Wagner, J. J., K. S. Lusby, J. W. Oltuen, J. Rakestraw, R. P. Wetteman, and L. E. WALTERS. 1988. Carcass composition in mature Hereford cows: estimation and effect on daily metabolizable energy requirement during winter. Journal of Animal Science 66:603-612.

Waldron, B. L., R. D. Harrison, A. Rabbimov, T. Mukimov, S. Y. Yusupov, and G. TuRsvnova. 2005. Forage kochia-Uzbekistan's desert alfalfa. Rangelands 27(1):7-12.

WelCh, B. L., AND J. N. Davis. 1984. In vitro digestibility of Kochia prostrata (L.) Schrad. Great Basin Naturalist 44:296-298.

Willms, W. D., L. M. Rode, and B. S. Freeze. 1993. Winter performance of Hereford cows on fescue prairie and in drylot as influenced by fall grazing. Canadian Journal of Animal Science 73:881-889. 